\title{
THE FUNCTION OF GOVERNMENT IN ITS RELATION TO INDUSTRY
}

\author{
By Joseph E. Davies, ${ }^{1}$
}

Chairman, Federal Trade Commission, Washington, D. C.

The subject "Relations of the United States with Central and South America as Affected by the European War," is fertile in its suggestion and most timely. The relations of this country with our neighbors of the South are brought forcibly to our attention by conditions precipitated by the European war. These relations are therefore interesting by reason of several factors in the situation, towit: the manner in which our industrial and financial organizations have been affected; the relations that will arise in a business and industrial way between the republics of this hemisphere by reason of the changing of the currents of the world's trade; and the manner in which these conditions will react upon the policies of the various sister republics of this hemisphere, where such policies are practically founded upon a common purpose and conception of the relation of government to industry.

With differing degrees of severity the European war has affected all the republies of this hemisphere, so far as industry, agriculture and finance are concerned, in much the same manner. We have all suffered by reason of this violent change in world conditions.

The possibilities of mutual advantage through the development of new courses in the world's trade and greater intensity of commercial development in the course of trade already established between this country and the governments to the south of us give great promise.

In the development and growth of the business of these countries it should be a matter of congratulation that, fundamentally, there is identity of outlook on the governmental policy which the respective governments take with reference to the relationship of government to industry.

${ }_{1}$ Remarks as presiding officer at the fourth session of the Nineteenth Annual Meeting of the American Academy held in Philadelphia on April 30 and May $1,1915$. 
In the evolution of industry and business the world over there are two types of governmental attitude that are fundamentally characteristic. Under the monarchical form there is a tendency toward centralization of power, not only in government, but as well in industry and finance, with the resultant disposition toward the recognition of monopoly, and indeed, perhaps, the fostering of monopoly, with the participation in the fruits thereof by the favored classes. Among self-governing peoples, on the other hand, there has crystallized a fundamental conception in national policies that there must be equality of opportunity in industry under a government that purports to be a government for the benefit of all the people; that the declaration of equal political opportunity is futile unless there be governmental policies that will preserve equality of opportunity for development consistent with the differences of abilities that reside in men. In other words, the policy of selfgoverning peoples, generally speaking, has been to develop such a governmental attitude as would preserve the channels of trade open through the processes of regulated competition, and practically all of the republics of the western hemisphere have that common attitude of the relationship of government toward industry.

By reason of this common point of view which pertains fundamentally to the governments of this hemisphere, there is great promise of future sympathetic and continuous coöperative development. This common outlook upon the functions of government has been supplemented as well, within the comparatively recent past, by developments of an international character which have created greater confidence in the integrity of motives of the Pan-American republics. I refer to the so-called Mexican Mediation Conference which was held with reference to the Mexican situation last year.

It is therefore but natural that trade should develop in greater and continuing measure between this country and the South American republics. We have not only a common point of view with reference to the function of government in its relation to industry, but also a greater degree of assurance in the integrity and disinterestedness of each other's motives. Trade, to exist and to grow, must be established not only upon mutual advantage arising through trade, but as well upon mutual confidence in the integrity of purpose and points of view of the people trading with each other. 